\title{
FRICTION BUFFER STOP DESIGN
}

\author{
Petr Guziur
}

\begin{abstract}
Institute of Railway Structures and Construction, Faculty of Civil Engineering, Brno University of Technology correspondence: guziur.p@fce.vutbr.cz
\end{abstract}

\begin{abstract}
Friction buffer stops are the favoured construction of buffer stop, mainly due to its high resistance and variety of layout. Last but not least is its manner of deceleration induced upon impact and during the braking what makes it smart solution in railway transport safety. The general approach of designing buffer stops is via usage of the kinetic energy and its conversion into work. Paper describes input parameters such as train velocity or buffer stop vicinity which is expressed by the safety coefficient implanted within the calculation. Furthermore, the paper shows the principle of calculation the friction buffer stop work, or to be more precise, the work of its braking jaws and optionally the work of additional braking jaws located behind the buffer stop. Last section of the paper is focused on the examples of designing friction buffer stops, points out the main complications and shows the charts of relation amongst braking distance, kinetic energy and braking force and the charts of relation between deceleration rate and braking distance.
\end{abstract}

KEYWORDS: buffer stop, kinetic energy, braking force, braking jaw.

\section{INTRODUCTION}

With increasing demands on safety in transportation, every threat needs to be considered. This means to keep safe onboard passengers and anyone who can be endangered in case of an accident. This applies even for buffer stops - especially for buffer stops at the dead-end tracks in stations by platforms with pedestrians.

The use of fixed buffer stops has become less suitable due to their low resistance and manner of deceleration, which arises in an order of tens of $\mathrm{m} . \mathrm{s}^{-2}$ [1] a clearly unacceptable state. According to the Czech Standard CD Z9 [2], it is allowed to design fixed buffer stop (Table 1). Using those constructions with very limited resistance is justified in particular cases such as deadend tracks in shunting yard, rolling stock depots etc.

Recently the motivation is to use more reliable constructions to increase the safety in railway transportation. The friction buffer stop with its high resistance and manner of deceleration is more suitable one.

\begin{tabular}{|l|l|l|}
\hline Buffer stop type & $\begin{array}{l}\mathbf{6} \text { cars of } \\
\mathbf{1 5} \mathbf{~ t}\end{array}$ & $\begin{array}{l}\mathbf{1} \text { car of } \\
\mathbf{8 0 ~} \mathbf{~}\end{array}$ \\
\hline Rail buffer stop & 1.0 & 1.6 \\
& $\mathrm{~km} \cdot \mathrm{h}^{-1}$ & $\mathrm{~km} \cdot \mathrm{h}^{-1}$ \\
\hline $\begin{array}{l}\text { Concrete type "SU- } \\
\text { DOP" }\end{array}$ & 0.7 & 1.1 \\
\hline Concrete type "DSB" & $\mathrm{km} \cdot \mathrm{h}^{-1}$ & $\mathrm{~km} \cdot \mathrm{h}^{-1}$ \\
& 1.0 & 1.6 \\
$\mathrm{~km} \cdot \mathrm{h}^{-1}$ & $\mathrm{~km} \cdot \mathrm{h}^{-1}$ \\
\hline
\end{tabular}

TABle 1. Resistances of buffer stops used in Czech Republic [2].

\section{FRICTION BUfFER STOP}

Friction buffer stops have become the preferred constructions at the end of a dead-end track in railway stations abroad (e.g. Switzerland, Germany [3, 4]). Resistance of a friction buffer stop (work of the buffer stop) could be much higher than a fixed buffer stop, and can be customized for various train mass, train speeds and acceptable deceleration rates.

Disadvantage of a friction buffer stop is obviously its space requirement due to its braking distance (see Figure 11.

Kinetic energy of moving train and its reduction along the braking distance is the criteria to calculate and design the buffer stop work. To be more precise the objective is to design the number of braking jaws and their braking distances.

There are two possibilities how to design the friction buffer stop:

- friction buffer stop without additional braking jaws (see Figure 1);

- friction buffer stop with additional braking jaws (see Figure 2).

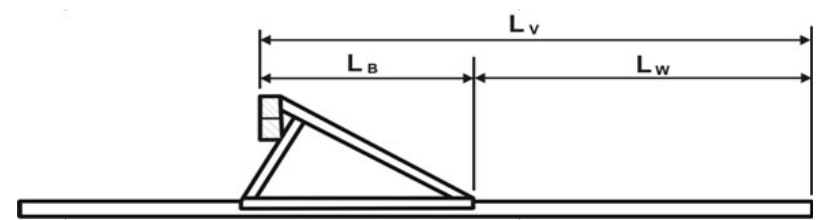

Figure 1. Friction buffer stop $[5]$.

$L_{V}$ - track length required for friction buffer stop

$L_{W}$ - braking distance

$L_{B}$ - buffer stop length 


\section{Buffer STOP DESIGN}

\subsection{Train Kinetic energy}

Defining the precise value of kinetic energy of moving rolling stock is to include rotating parts into calculation. To simplify the calculation of train kinetic energy one can use Formula 1 for calculation the kinetic energy of non-rotating object of certain mass and velocity.

$$
E_{k i n}=\frac{1}{2} m v^{2}
$$

$E_{k i n}$ - train kinetic energy $[\mathrm{J}]$

$m$ - train mass $[\mathrm{kg}]$

$v$ - train velocity by impact $\left[\mathrm{m} . \mathrm{s}^{-1}\right]$

\subsection{COllision SPEed}

Collision speed is probably the most questionable parameter entering the calculation. In tracks with train control system, which can interfere with driver inappropriate driving (e.g. ETCS) - in this case an insufficient braking at the end of dead end track, it is possible to define the collision speed. Nevertheless, there are numerous dead-end tracks without any speed controlling system and therefore the driver is responsible for proper braking.

Collision speeds that could be found in literature are $V=10 \mathrm{~km} \cdot \mathrm{h}^{-1}$ or $V=15 \mathrm{~km} \cdot \mathrm{h}^{-1}$ (depends on train type or track type) $4-6$.

\subsection{SAFETy COEFFICIENT}

For including an inaccuracy entering the calculation of kinetic energy and to ensure the reliability of the design, safety coefficient $k$ has to be counted in calculation. The value of the coefficient varies and depends on type of train, location of dead end track etc. Various infrastructure managers approach towards the assessment of the safety coefficient differently. Values of safety coefficient usually varies between 1,0-2,0 [3, 4, 6.

\begin{tabular}{|l|c|}
\hline Type of train & $k[-]$ \\
\hline Freight trains and shunting & 1.2 \\
\hline $\begin{array}{l}\text { Passenger trains, freight trains and shunt- } \\
\text { ing, when it is necessary to protect various }\end{array}$ & 1.5 \\
$\begin{array}{l}\text { systems which are located behind or nearby } \\
\text { buffer stop }\end{array}$ & \\
\hline $\begin{array}{l}\text { All trains, where there are traffic zones, struc- } \\
\text { tures or residential buildings located behind } \\
\text { or nearby buffer stop }\end{array}$ & 1.8 \\
\hline $\begin{array}{l}\text { Preventing the fall of any train or rolling } \\
\text { stock into an abyss }\end{array}$ & 2.0 \\
\hline
\end{tabular}

TABle 2. Safety coefficient [6].

\subsection{BUfFER STOP WORK}

In general, the resistance of buffer stop is described as its energy absorbing capacity, therefore the buffer stop work required to stop the train. In case of friction buffer stop, it is the work of braking jaws $W$ with braking forces $F_{b, i, j}$ on braking distances $l_{i, j}$. Work of the braking jaws can be obtained using Formula 2 and 3

$$
\begin{gathered}
W_{i}=n_{i} * \sum_{j=1}^{n} F_{b, i, j} * l_{i, j} \\
W=\sum_{i=1}^{s} W_{i}
\end{gathered}
$$

$W_{i}$ - work of $i$-group of braking jaws $[\mathrm{J}]$

$n_{i}$ - number of braking jaws in $i$-group [-]

$F_{b, i, j}$ - braking force of a single braking jaw, based on a braking distance $[\mathrm{N}]$

$l_{i, j}$ - length of braking distance of $i$-group of braking jaws, based on $L_{W}[\mathrm{~m}]$

Braking force of each braking jaw decreases along the braking distance 4 .

\begin{tabular}{|l|l|}
\hline $\begin{array}{l}\text { Length of } \\
\text { braking } \\
\text { distance } \\
l_{i, j}[\mathrm{~m}]\end{array}$ & $\begin{array}{l}\text { Braking } \\
\text { force } F_{b, i, j} \\
{[\mathrm{kN}]}\end{array}$ \\
\hline $0-5$ & 40 \\
\hline $5-8$ & 36 \\
\hline $8-12$ & 32 \\
\hline $12-20$ & 28 \\
\hline
\end{tabular}

TABLE 3. Braking force of a braking jaw along the braking distance [4].

The design of friction buffer stop (number of braking jaws and their braking distances) is correct if the buffer stop work is equal or higher than the train kinetic energy increased by the safety coefficient:

$$
W \geq E_{k i n} * k
$$

\subsection{DeCELERATION RATE}

Deceleration rate could be the limiting parameter when designing number of braking jaws and their braking distances. The most challenging design comes with dead-end track where parameters of trains vary (mostly the train mass). Deceleration rate has to be monitored both upon impact and along the braking distance where additional braking jaws could be designed. Fortunately, restriction in deceleration rate applies only to the passenger trains. Maximal deceleration rate is set as $a=2.5 \mathrm{~m} . \mathrm{s}^{-2}$ [7]. Deceleration rate is calculated as follows:

$$
a_{\max }=\frac{F_{\max }}{m}
$$




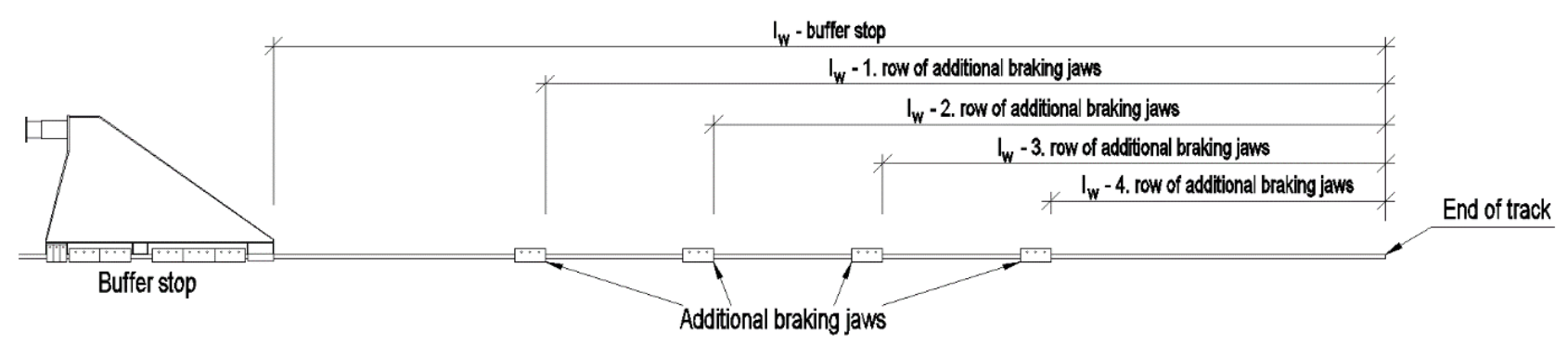

Figure 2. Buffer stop with additional braking jaws.

\author{
$a_{\text {max }}$ - maximal deceleration rate $\left[\mathrm{m} . \mathrm{s}^{-1}\right]$ \\ $F_{\max }$ - maximal braking force along the braking \\ distance $[\mathrm{N}]$ \\ $m$ - train mass [kg]
}

\subsection{Design PROCEDURE}

The design of buffer stop is customized for two types of trains, the lightest one and the heaviest one running on the dead-end track. This approach covers both deceleration rate restriction (usually the limiting factor for light trains) and the highest value of kinetic energy of heavy train (sufficient work of the buffer stop).

Braking distance for braking jaws on buffer stop is considered as the main braking distance. The tricky part comes with additional jaws behind the buffer stop thus in their braking distances where each pair of additional braking jaws has different braking distance. Therefore it is necessary to consider the variable braking force for each pair of additional braking jaws along the braking distance according to Table 3

For better understanding, see following examples.

\subsubsection{EXAMPLE 1}

As it was described in Section 3.6 two types of trains were selected for calculation. A light train with mass of $170 \mathrm{t}$ and a heavy train with mass of $300 \mathrm{t}$. Collision speed of trains $V=15 \mathrm{~km} \cdot \mathrm{h}^{-1}$, is the same for both of them, and safety coefficient used to increase the kinetic energy $k=1,8$ (see Section 3.3).

In this situation, the main braking distance is set to $11,3 \mathrm{~m}$ ( $l_{w}$ - buffer stop) with five pairs of braking jaws and one pair of additional braking jaws with braking distance of $4,0 \mathrm{~m}\left(l_{w}-1\right.$. row of additional braking jaws). Under those circumstances, the mass of the light train is high enough to design the large number of braking jaws on buffer stop and the limit of deceleration rate is not exceeded. Nevertheless, the offset for the first row of additional braking jaws behind the buffer stop must be set. If the light train reaches the additional braking jaws, braking force will increase and therefore the deceleration rate will increase over the limit. 4.

For better understanding, see Figure 3 and Figure

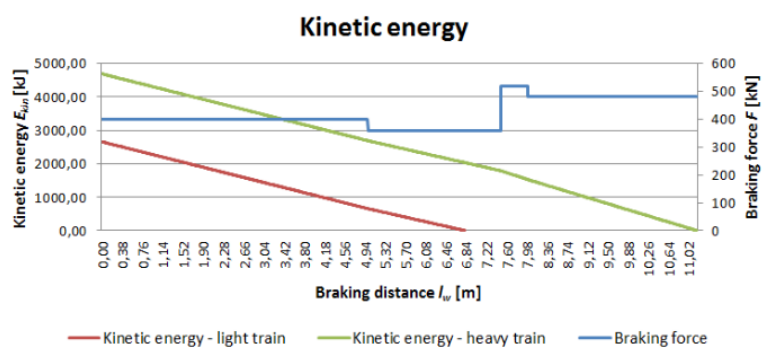

FiguRE 3. Kinetic energy and braking force along the braking distance (Example 1).

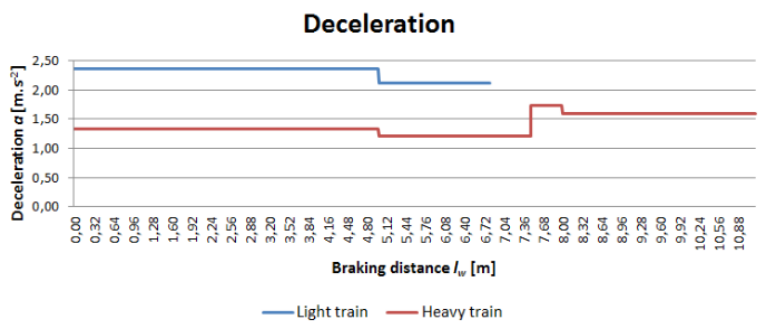

FIgURE 4. Deceleration rate along the braking distance (Example 1).

\subsubsection{EXAMPLE 2}

In this example, the light train with mass of $80 \mathrm{t}$ and the heavy one with mass of $300 \mathrm{t}$ were selected to point the difficulty and variety of design. Collision speed of trains $V=15 \mathrm{~km} \cdot \mathrm{h}^{-1}$ is the same for both of them and the safety coefficient used to increase the kinetic energy $k=1,8$ was chosen (see Section 3.3.

In this case, the main braking distance is set to 15,5 $\mathrm{m}\left(l_{w}\right.$ - buffer stop) with just 2 pairs of braking jaws and three rows of additional braking jaws. Each row of additional braking jaws consists of 2 pairs of braking jaws. Braking distances are designed as follows: 7,0 $\mathrm{m}\left(l_{w}-1\right.$. row of additional braking jaws $), 5,5 \mathrm{~m}\left(l_{w}\right.$ - 2. row of additional braking jaws) and 4,0 $\mathrm{m}\left(l_{w}-\right.$ 3. row of additional braking jaws). The mass of light train is significantly lower and one has to design fewer braking jaws on buffer stop in order not to exceed the limit of deceleration rate. The offset of first row of additional braking jaws has to be set similarly to example one. 


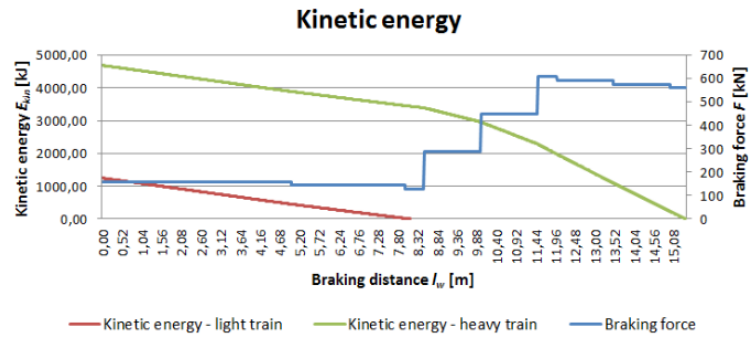

FiguRE 5. Kinetic energy and braking force along the braking distance (Example 2).

Deceleration

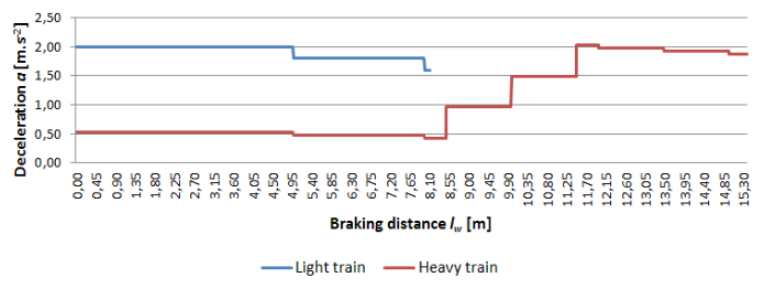

FiguRE 6. Deceleration rate along the braking distance (Example 2).

\section{Conclusion}

The usage of the fixed buffer stops in the railway stations is slowly becoming an anachronism. One can still come across many of those constructions in present railway stations but the latest progression, is to design buffer stops with high resistance and high level of safety.

Friction buffer stops meet those criteria in every point. The possibilities variety of designing the friction buffer stop is the huge advantage. The range of options varies form light trains with low collision speed, up to heavy trains with high collision speed.

The paper discusses the parameters of the buffer stop and shows some examples of design for certain situations. As described above, design buffer stop for some combinations of trains on dead-end track could be challenging while all criteria, such as buffer stop kinetic energy absorbing capacity, restriction of deceleration rate and space options, must be met.

\section{ACKNOWLEDGEMENTS}

The paper was created with support of the project no. LO1408 "AdMaS UP - Advanced Materials, Structures and Technologies" supported by the Ministry of education, youth and sports within the targeted support of program "National program for sustainability I" and student's grant tender of the Faculty of Civil Engineering, Brno University of Technology (FAST-J-16-3776).

\section{REFERENCES}

[1] M. Bugarín, J.-M. Díaz-De-Villageas. Conception of buffer stop blocks [online]. 2001. [cit. 2016-11-10] "http://www.railway-research.org/IMG/pdf/329.pdf".

[2] C. Z9. Železnični spodek, Vzorový list železničního spodku, Zarážedla. České dráhy, s.o., Divize dopravní cesty, o.z., Praha, 2001. In effect from 1.4.2002.

[3] Ausführungsbestimmungen zur Eisenbahnverordnung / AB-EBV, 2014. Artikel: Gleisabschluss, Bern.

[4] DB:DS 800 01. Bahnanlagen entwerfen - Allgemeine Entwurfsrichtlinien.

[5] I. R. LTD. Railway buffer stops planning guidlines [online]. 2009. [cit. 2016-11-05]

"http://www.iroads.co.il/sites/default/files/imce/ ir_buffer_stops_guidelines.doc".

[6] RVE 05.05.31 Oberbau, Oberbaukonstruktionen, Gleisabschlüsse. Wien. 2014.

[7] Guide for the application of TSI LOC\&PAS. Version 2.0, 2015. European Railway Agency, France. 